\title{
Access denied: understanding the relationship between women and sacred forests in Western India
}

\author{
Shruti Mokashi and Stewart A. W. Diemont
}

\begin{abstract}
Sacred forests or groves are patches of forest vegetation that are traditionally protected by local communities because of their religious or cultural significance. The ecological aspects of sacred forests have been the focus of most of the scholarly discourse; little scholarship has examined how local people perceive their sacred areas. This scholarly lacuna is especially pronounced with respect to women, as the majority of sacred forests have traditionally been the domain of the men. Until recently, the sacred forests tradition in most regions endured with minimal participation of women, but with changing socio-economic and cultural conditions, sacred forests are declining. By examining women's perspectives regarding their relationship with their sacred forests, this research informs the scholarship on gender and sacred forests, and explores the role women can play in forest conservation. In 2015-2017, we conducted village meetings and in-depth interviews in four villages located in and around the Bhimashankar Wildlife Sanctuary in the Western Ghats region of Maharashtra state, India. We found that apart from rules and taboos governing the protection of these sacred forests, taboos also revolve around the access and interaction of women with the sacred forests, with women having less control and decision-making power than men. Nevertheless, women expressed interest in continuation of the tradition of sacred forests, and the younger generation wants some of the gendered rules to change. We recommend including women in management and decisionmaking processes to strengthen the institution of sacred forests.
\end{abstract}

Keywords Community-based conservation, conservation, gender, India, perceptions, sacred forests, taboos, women

\section{Introduction}

T m many societies, natural areas or landscapes are deemed 1 sacred. Wild \& McLeod (2008, p. 5) define 'sacred natural sites' as 'areas of land or water having special spiritual

SHRUTI MOKASHI (Corresponding author, (D) orcid.org/0000-0002-0043-1893) Ashoka Trust for Research in Ecology and the Environment, Royal Enclave, Sriramapura, Jakkur Post, Bangalore 560064, Karnataka, India

E-mailsamokash@syr.edu

Stewart A. W. Diemont (Di) orcid.org/0000-0001-8575-6285) Department of Environmental Biology, State University of New York, College of Environmental Science and Forestry, Syracuse, New York, USA

Received 7 April 2020. Revision requested 3 June 2020.

Accepted 14 October 2020. First published online 1 September 2021. significance to peoples and communities'. Sacred forests, also known as sacred groves, are a type of sacred natural site where patches of forest are protected and revered because of their association with a deity, spirits or ancestors. In the most general and simplistic terms, sacred forests can be defined as traditional community-conserved forest patches that hold high cultural or spiritual significance for local people (Ormsby \& Bhagwat, 2010). Inside the sacred forests, festivals, ceremonies and rituals are performed, and offerings are made. The size of sacred forests may range from a cluster of a few trees to thousands of hectares. They have been documented in Africa, Asia and the Mediterranean (Gadgil \& Vartak, 1976; Chandran \& Hughes, 2000; Sheridan \& Nyamweru, 2008; Ormsby \& Bhagwat, 2010; Allendorf et al., 2014). Here the term 'sacred forest' or 'sacred grove' is used for forest patches that are deemed sacred by the community and 'forests' refers to non-sacred forests.

Sacred forests are managed and protected through a system of taboos, norms and sanctions, thus resulting in forest conservation. Hence they have been receiving increased international attention because of their forest and biodiversity conservation potential (Kent, 2013); this potential coupled with local community involvement makes them a powerful conservation approach (Ormsby \& Bhagwat, 2010). Concerns have emerged, however, over the decline of sacred forests (Chandrakanth et al., 2004; Ormsby, 2013). They face numerous threats from development, commercial forestry, Sanskritization (a process in which local deities are replaced with mainstream Hindu deities, thus resulting in temple construction inside sacred forests; Bhagwat \& Rutte, 2006), shift in belief systems, cultural change, pilgrimage and tourism, removal of biomass, invasive species, encroachment, modernization and market forces, and fragmentation and perforation (Malhotra et al., 2001; Ormsby \& Bhagwat, 2010; Kandari et al., 2014).

Local communities are instrumental in maintaining these sacred forests, and so an understanding of their perceptions of and relationships with sacred forests is important. Although there have been numerous studies on the ecological significance, biodiversity and conservation importance of sacred forests (see review by Ray et al., 2014), there have been few about how sacred forests are perceived by the local communities that protect them (Ormsby, 2013). This is more pronounced with respect to women (Malhotra et al., 2001) because, although sacred forests have been hailed as a community conservation model, women remain on the sidelines of sacred forest management (Singh, 2006; 
Kent, 2013; Acharya \& Ormsby, 2017). There are only a few documented exceptions. In Sierra Leone the sacred forests, sande, are under the exclusive control of women (Lebbie \& Freudenberger, 1996). In Okinawa, Japan, women's control extends beyond the sacred forests: they are the acknowledged and respected leaders of the local religion and hence are the principal priestesses in the community (Sered, 1999).

To address this gap in scholarship, we explore the perspectives of women towards their sacred forests, the taboos surrounding sacred forests, and the future changes they expect. This research is a part of a study that examined community perceptions of and relationship with sacred forests. Additionally, we suggest that, as threats to sacred forests are increasing and the institution is crumbling, women can play more active roles in the management of sacred forests. This would not only help in strengthening the institution but also in reviving it in places where it has been degraded.

\section{Study area}

This study was carried out in the region of Bhimashankar Wildlife Sanctuary in Western India. The Sanctuary lies in the northern Western Ghats in the state of Maharashtra, 110 $\mathrm{km}$ from Pune. Sacred forests are common in the Western Ghats (Chandran, 1998; Bhagwat et al., 2005, 2013), and Bhimashankar is well-known for its sacred village forests. The c. $131 \mathrm{~km}^{2}$ Sanctuary (Rao et al., 2008; Fig. 1) was gazetted by the Maharashtra government in 1985 under the Wild Life (Protection) Act of 1972. The Sanctuary is named after the Bhimashankar temple, which is located within the Sanctuary. The Sanctuary and its surrounding region comprise mountain ranges, valleys, rivers, forests, agricultural fields, villages and sacred forests.

Bhimashankar Sanctuary includes the crest of the Western Ghats, the steep western slopes, and some of the spurs running into the eastern plains, along with valleys, gorges and plateaus (Borges, 1996; Mahabal, 2009), at altitudes of $340-1,208 \mathrm{~m}$ (Mahabal, 2009). The Sanctuary is under the administrative control of the Maharashtra Forest Department, Conservator of Forests (Wildlife), Pune. The two main rivers in the region are the Bhima and the Ghod, which originate in the western part of the Sanctuary and flow eastwards. The Bhimashankar region experiences three seasons: summer, monsoon and winter. Mean maximum and minimum temperatures are 36 and $7{ }^{\circ} \mathrm{C}$, respectively, and mean annual rainfall is $3,000 \mathrm{~mm}$, mostly falling during the monsoon. The Sanctuary harbours a diverse flora and fauna, including endemic species. A total of 529 animal species have been recorded (Zoological Survey of India, 2009), including 236 bird species, 66 mammals, 54 reptiles (one turtle species, 18 lizards and 35 snakes), and 65 butterfly species. The majority of the vegetation belongs to

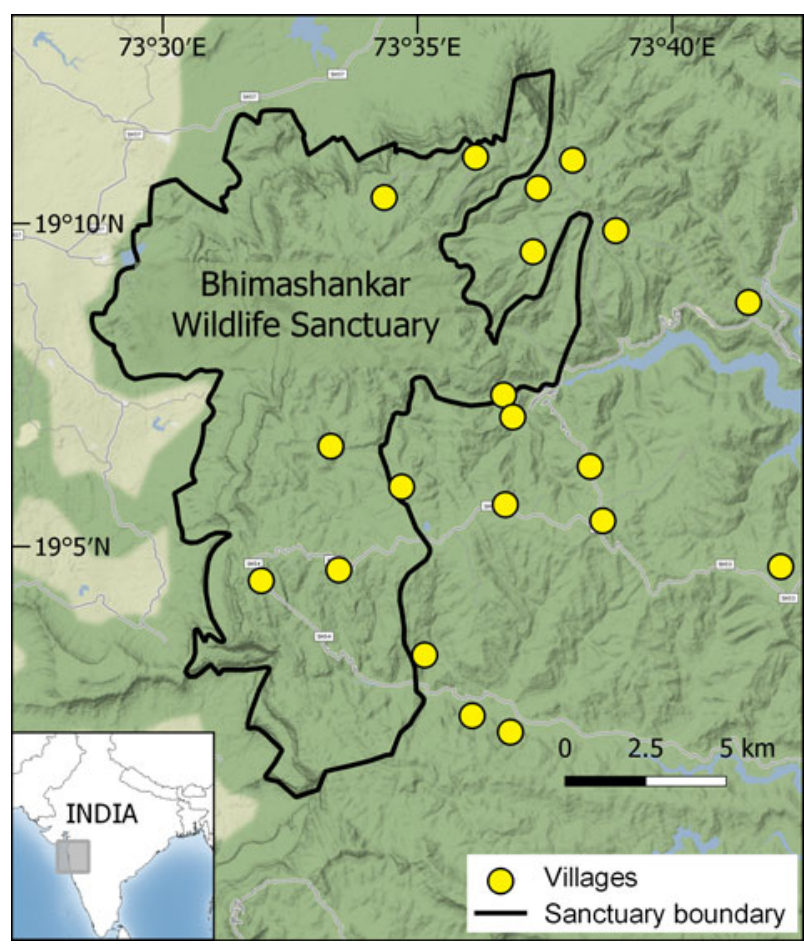

FIG. 1 Bhimashankar Wildlife Sanctuary and the surrounding region, with the locations of the 20 villages where we made preliminary visits during 2015-2016. (Base map by Stamen Design, under CC BY 3.o.)

the western subtropical broadleaved hill-forests type, also known as montane broadleaved semi-evergreen forest (Rahangdale \& Rahangdale, 2017).

The Bhimashankar region is inhabited primarily by the Mahadev Koli tribal community, along with a smaller population of Katkaris and Dhangars, settled in villages, some of which comprise numerous hamlets. After the declaration of the Sanctuary in 1985, a few villages came to be within its boundaries, and thus the Sanctuary includes village, communal and privately owned agricultural lands and forests. The majority of this private land is owned by the Mahadev Koli tribal community. Ten villages lie within the boundaries of the Sanctuary and 111 lie within $10 \mathrm{~km}$ (Pande \& Pathak, 2005). For this study, we considered villages located within the Sanctuary and those within $10 \mathrm{~km}$ of the Sanctuary boundary.

The Mahadev Koli is one of the scheduled tribes of India. They are a forest-dependent community engaged in agriculture, cattle rearing, the sale of milk and milk products, and the collection and sale of non-timber forest products (NTFPs). Shifting cultivation was widely practiced in this region before the consolidation of forests under British rule (Rao et al., 2008), after which people began to cultivate rice and other crops. Shifting cultivation is, however, still practised on a smaller scale, with varieties of millet such as nachani Eleusine coracana, varai Panicum sumatrense and sawa Panicum millaere. Although cultivation and cattle 
TABLE 1 The number of respondents in each age group in the four villages (names anonymized).

\begin{tabular}{|c|c|c|c|c|c|c|c|c|c|}
\hline \multirow[b]{2}{*}{ Age (years) } & \multicolumn{2}{|l|}{ A } & \multicolumn{2}{|l|}{ B } & \multicolumn{2}{|l|}{$\mathrm{C}$} & \multicolumn{2}{|l|}{$\mathrm{D}$} & \multirow[b]{2}{*}{ Total } \\
\hline & Men & Women & Men & Women & Men & Women & Men & Women & \\
\hline $18-30$ & 0 & 1 & 4 & 3 & 2 & 4 & 3 & 4 & 21 \\
\hline $31-45$ & 3 & 3 & 2 & 2 & 3 & 0 & 3 & 2 & 18 \\
\hline $46-60$ & 1 & 1 & 6 & 2 & 2 & 3 & 4 & 6 & 25 \\
\hline $61-75$ & 1 & 1 & 2 & 1 & 3 & 1 & 1 & 0 & 10 \\
\hline $76-100$ & 2 & 0 & 2 & 2 & 1 & 0 & 4 & 1 & 12 \\
\hline Total & 7 & 6 & 16 & 10 & 11 & 8 & 15 & 13 & 86 \\
\hline
\end{tabular}

breeding are common occupations, increasingly the younger generation is working in neighbouring towns and cities, in education, service and industry. The language spoken among these communities is Marathi.

\section{Methods}

The total number of village sacred forests in the Bhimashankar region has not been fully documented, although Pande \& Pathak (2005) estimated there are 14 sacred forests within the Bhimashankar Wildlife Sanctuary, and Deshmukh (1999) and Burman (2003) also documented sacred forests in this region. Based on these studies, we estimated there are 30-40 sacred forests in the region, with some villages having several. Using the villages mentioned in these studies as a reference, SM conducted preliminary visits to 20 villages (Fig. 1) during 2015-2016. Kalpavriksh, an environmental NGO, facilitated contact with three people local to the region to accompany SM.

Of these 20 villages we found three no longer had sacred forests, although the temple or the deity shelter were extant, and three village sacred forests were either neglected or highly degraded, with only the major trees standing and the undergrowth cleared. We therefore considered 14 of the 20 villages for study. Based on the location of theses villages (selecting villages not close to each other), ownership of the land on which the sacred forests were located (community, private or Maharashtra Forest Department), and accessibility, we selected five villages for in-depth study. We could not obtain community consent for research in one of these villages, and therefore interviews were conducted in four villages, which we refer to as $\mathrm{A}, \mathrm{B}, \mathrm{C}$ and $\mathrm{D}$ (the names have been anonymized to protect the communities from any unintended harm).

Ethnographic methods, in particular semi-structured interviews, were used to gather data. Although four communities were involved, the unit of analysis was the individual. We used convenience and snowball sampling to select participants for interview (Bernard, 2006; Newing et al., 2011). Additionally, targeted sampling (Bernard, 2006) was used to seek out key informants such as priests and elders. Preliminary visits, community consent meetings, and the interviews were conducted over 18 months from mid 2015 to the beginning of 2017 .

Eighty-six in-depth interviews were conducted along with group and community meetings. Table 1 details the respondents in each village by gender and age group. Being a woman allowed SM to approach women easily and, additionally, two of the local contacts were young women and were able to introduce SM to other women in the villages. Interviewees usually invited SM to enter their house. On many occasions interviews were conducted whilst the women were cooking, cleaning or sweeping. The interviews were recorded, and later translated and transcribed. The transcriptions were coded and analysed using ATLAS.ti 7.5 (Scientific Software Development GmbH, Berlin, Germany). For coding both hypothesis and provisional coding were used (Saldana, 2009). To maintain the anonymity of the respondents, each was assigned a number based on their village. Thus the first respondent or interviewee in Village $A$ is $A_{1}$, the second is $A_{2}$, and so on.

\section{Results}

We initially discuss the characteristics of the sacred forests in the studied villages and then our findings regarding women's perspectives of and relationships with sacred forests and other forest areas.

\section{Sacred forests}

The sacred forests we observed in the Bhimashankar region were associated with villages or their hamlets and were locally known as ban or devache ban, which means God's forest. The location of the sacred forests varied from mountain top to valley, and from the interior of forest accessible only by foot to beside roads, and were located in a matrix of villages, agricultural fields and other forest areas (Table 2). Area ranged from a clump of trees to 5-6 ha (Plate 1). Although small, the sacred forests were generally biodiverse, although a few were dominated by only one type of tree species, such as bamboo Bambusa bambos or fishtail palm Caryota urens. A few sacred forests had water wells or streams flowing beside them and were a source of drinking 
TABLE 2 Characteristics of the four study villages (names anonymized).

\begin{tabular}{lllll}
\hline Characteristic & A & B & C & D \\
\hline Number of hamlets & 1 & 1 & 2 & 3 \\
Approximate population & 450 & 450 & 250 & 600 \\
Approximate \% who are members of scheduled tribes & 95 & 85 & 95 & 80 \\
Ownership of the sacred forests & Community & Community & Maharashtra & Community \\
& land/private land & land/private land & Forest Department land & 250 \\
Distance from sacred forest (m) & 900 & 500 & 50 & Adjacent \\
Distance from nearest other forest patch (m) & Adjacent & 20 & No & Yes \\
Tarmac road access to sacred forest & No & Yes & Yes & Yes \\
Women allowed in sacred forest & No & No & No & No \\
Women allowed in temple inside sacred forest & No & &
\end{tabular}

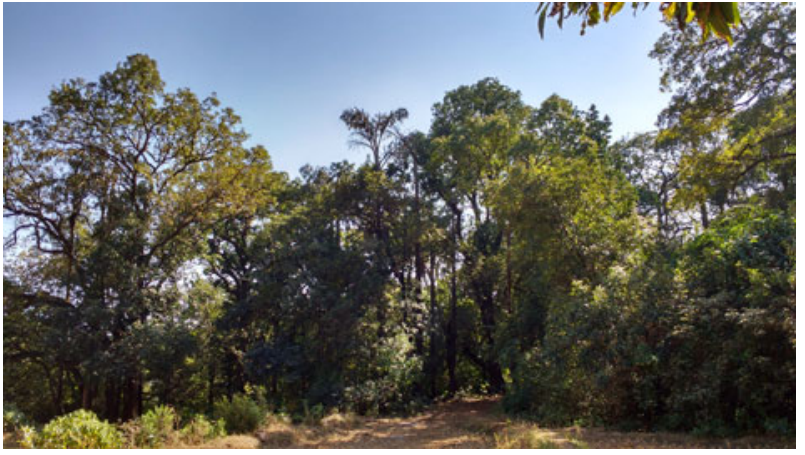

Plate 1 A sacred forest in the Bhimashankar region, Western Ghats, Maharashtra state, India (Fig. 1). Photo: Shruti Mokashi.

water for the village. A majority had temple structures that housed the deity: some were simple, with red bricks and roof tiles, and others were domed concrete structures. The responsibility of looking after the deity and performing daily rituals lay with one of the community's families, with the men acting as the priests. This responsibility was passed between generations. Decisions regarding festival management and temple construction were taken mostly by the village men, along with the priest. Occasionally some of the traditions were altered when the village deemed it necessary, such as altering the duration of a festival, or adding new events to the festivals.

Numerous taboos governed the management and protection of these sacred forests. Taboos were in place forbidding tree cutting, hunting and extraction of fuelwood from the sacred forest, use of kerosene for domestic purposes in the sacred forest, entry of women in the temple, and wearing of footwear by women in the sacred forest. The sacred forests were facing threats from development projects, temple building, pilgrimage and tourism, encroachment, and forest fragmentation and perforation. Some of the sacred forests had already disappeared. During preliminary field visits we observed that sacred forests were not present in some of the villages where Deshmukh (1999) had documented them, and in others they were in a degraded state. This indicated that the traditional sacred forest system is weakening.

\section{Community interaction with other forest areas}

The interviews revealed that women in the Bhimashankar region had a close relationship with forests and regularly ventured into forest areas to extract fuelwood and forest products, and to graze animals. Fuelwood is an important forest product, used for cooking and heating. Only some families had access to liquefied petroleum gas (LPG) cylinders to use as cooking fuel. Heating requirements were not met with LPG but rather with fuelwood, which was extracted both by men and women. Timber was also formerly extracted for construction of houses, but there had been a reduction in this use, as people had constructed brick or concrete structures.

Most of the women mentioned they extracted fruits, wild vegetables and crabs for consumption. They collected and sold the fruits of hirda Terminalia chebula, shikakai Acacia concinna, beheda Terminalia bellirica and other commercially important forest products. Elderly and middle-aged women were knowledgeable regarding the names of wild vegetables and forest products and the ways to extract them. Some men extracted honey from the forest, for sale.

\section{Women and sacred forests}

When asked about the sacred forests, most of the women mentioned deep reverence and faith in the deity. They indicated that the relationship they had with the sacred forest was because of the deity's presence there. The women also expressed a belief that the sacred forest was the deity's home as it '. . . shelters the deity' (D12; age 29; education up to grade 6, 11 years old), and further stated that everything in the sacred forest belonged to the deity. The sacred forests were perceived by most of the women in the context of tradition and they said they followed the tradition because their elders followed it.

Although the sacred forest space is revered by both men and women, the majority of the rituals and ceremonies are controlled by men. Women went into the sacred forest 
mostly during festivals such as the annual Saptah, but did not enter the temple, worshipping from outside. Women were primarily given the responsibility to cook for the feasts and to clean. In other festivals such as the Saath, performed before sowing and harvesting of crops, only men participated in the rituals.

Women spoke of the taboos that restricted their movement in and around sacred forests. They were not allowed to enter some sacred forests nor any of the temples dedicated to the male deities, particularly that of Vandev. Men and children (including young girls) could enter the temple and worship. As one woman stated, 'We women do not enter the temple. Only men enter the temple' $\left(\mathrm{C}_{3}\right.$; age c. 65). As access to temples was denied to women, they had no reason to enter the sacred forests other than during festivals or other special occasions.

An exception to this rule is that women were allowed in temples and sacred forests dedicated to female deities such as Kalamjai. But even in places where women were allowed to enter the sacred forest or the temple or both, they were forbidden to do so during menstruation or if they were pregnant. As one woman said, 'Women do not enter the sacred forest if menstruating. They go around the sacred forest' (D1; age c. 6o).

The main taboos responsible for the maintenance of sacred forests were prohibitions on tree cutting and extraction of fuelwood. These were widely mentioned taboos and most women said they adhered to it. One respondent stated, 'It is God's forest, that's why we don't even burn the fuelwood from there. We follow the rules. We don't cut wood from the sacred forest at all. The fuelwood from the sacred forest is not to be used in the kitchen. The way we believe in the deity similarly we also believe in the trees' (B17; age 40).

Most of the women believed that if they break the taboos regarding fuelwood extraction or enter the sacred forests or the temple, this would anger the deity and could result in harmful consequences. Taboos and rules were followed because they were traditional and ancestral. For instance, a young woman said, 'People from my house told me about the sacred forest and the rules. If you transgress the rules you get punished' (A4; age 22; education up to grade 9, 14 years old). Similarly another woman said, 'The rules were made by the forefathers. My in-laws told me not to go there, not to do this; I followed that' ( $C_{3}$; age 65$)$. Women also believed that the taboos are in place for the benefit of the community and hence should be followed.

As a woman, the same taboos were applicable to SM. During interviews, when asking about the taboos, on most occasions the taboos regarding women were mentioned first and in some cases these were emphasized by both men and women, perhaps because a woman was asking them these questions.

Their limited access to sacred forests had affected women's perspectives and knowledge regarding the sacred forest's biodiversity. When asked about what kind of trees or animals are found inside the sacred forest, many women had no knowledge of this. The common response was that as women are not allowed there, they do not know much or have no knowledge of the sacred forest. Some women were reluctant to answer questions and deferred to men if they were present. For instance, two women kept mentioning that the author should have spoken to the man of the house. 'If that man would have been home you would have got more information ... he would have told you everything from “A to Z"...' (B13; age 26).

\section{Changing perspectives and interactions with sacred forests}

We observed that elderly and middle-aged women wanted the tradition and rules regarding women and sacred forests to continue as they were. When asked whether the same rules should be in place for men and women and whether women should be allowed to enter, a middle-aged woman became offended and said, 'Those are your opinions and these are ours' (D11; age 40). When the rules were not followed by younger women, this was frowned upon by the older women.

Nevertheless, most of the younger women noted that, although the taboos on tree cutting and extraction of forest resources should continue, they would like a change in the rules and taboos regarding access. One woman said, 'I do not think the God will get angry if girls go to the temple. What do you think? Is it not true? The people from earlier generations have been following these rules, and so they are being carried forward...' ( $\mathrm{C}_{4}$; age 30 ; education up to grade 8, 13 years old). Regarding the future of sacred forests, some women expressed uncertainty, for instance, 'In future people will follow this tradition or not; how can we tell...' (B13; age 26). Others expressed concern and made suggestions regarding reforestation. For example, one woman said, "The sacred forest will not remain in future. The trees are old and dying and if new trees are not planted then the sacred forest won't survive. Trees such as mango should be planted in the sacred forest. The tradition of sacred grove is good but then everybody should follow the rules and they should be same for everyone' (D23; age 24; Education: graduate degree). Some older women also hoped that new saplings could be planted in the sacred forest, 'We want flowering plants/trees in front of the temple... for the deity' (A1; age 45). Another woman said that things will change in the future, especially those with respect to women's access, but also expressed hope regarding the sacred forests:

Rules regarding women and footwear should be changed. Even women should be allowed to go inside the temple and worship. Maybe the rules for menstruation are alright but otherwise there should be equality between both the genders (as regards rules). Personally I feel these rules 
will not be followed. But the grove will stay. Ceremonies will continue The temple structure can grow bigger. I feel people won't cut trees. I feel if more protection is provided it will remain the same. If trees are planted-fruit bearing, medicinal varieties and local native species-the sacred forest will become denser' (D18; age 23; Education: graduate degree).

Young men also seemed more accepting than older men of a change that would allow women access to sacred forests. For example, one young man from village $\mathrm{C}$ said, 'I mean both men and women are equal so even if ladies go there in the temple it should not be a problem. That rule should have been changed' (C11; Age 25; Education: Diploma in Education). The women in a family from Village D told about an activity that speaks about their sustainable management attitude: 'Our family has been collecting medicinal plants from the sacred forests for the last 3 years. While extracting we keep one bulb for future regeneration.'

With the help of local NGOs, many villages in the Bhimashankar region have been working towards securing tenure rights to forests under the Scheduled Tribes and Other Traditional Forest Dwellers (Recognition of Forest Rights) Act, 2006. The Community Forest Resource rights is a pioneering provision that gives local communities (i.e. the Gram Sabha, which is a village assembly consisting of both men and women adult members) the right to protect, manage and conserve forest areas. Additionally, Kalpavriksh, an environmental NGO, has been working with women's self-help groups in the region, reviving biocultural diversity through uncultivated and wild food festivals (which SM attended), and have also developed a women's local honey enterprise, buying local honey and processing and packaging it for sale.

\section{Discussion}

\section{Women's access to sacred forests}

Religion plays an important role in implementing social boundaries with respect to a particular natural resource, by prohibiting the access of either men or women to that resource (Cox et al., 2014). This role is evident in the Bhimashankar region, where traditional rules curtail women's access to and control of these sacred forests.

Researchers in the Indian sub-continent have noted the gender-specific restrictions imposed on women regarding entry and involvement in the management of sacred forests. Menstruating and pregnant women are not allowed to enter the sacred forest because they are considered to have a polluting effect. In southern India, pollution (Tittu) is one of the main elements in Tamil religiosity (Kent, 2010). This pollution is conceived as some invisible substance which emanates during death and menstruation. If this rule is transgressed, it angers the deity, and the woman or the community face consequences. Similar observations have been made in sacred forests in the state of Kerala, where polluting activities are supposed to anger the snake gods (Notermans et al., 2016), and in the state of Madhya Pradesh (Kala, 2011), and in sacred forests in Maharashtra (Singh, 2006).

In the sacred forests that we observed in the Bhimashankar region, women were allowed to enter both the temples and the sacred forests that were dedicated to female deities. In the devithans in Sikkim, India, where the deity in these sacred forests is a goddess (devi translates to goddess), Acharya \& Ormsby (2017) posited that, in the case of devithans that act as source of water, women may have been allowed to enter because of the need to draw water, thus resulting in a deviation from imposing a sanction on the entry of women.

In forest-dependent communities women play an important role in the extraction of forest products, and in some regions they are the primary harvesters of products such as fuelwood, fodder and leaf litter for daily needs (Agarwal, 2009). Singh (2006) noted that some of her interviewees suggested women are restricted from entering the sacred forests because they are mostly responsible for fuelwood collection and hence the restriction may be a way of protecting the sacred forest. But she challenges this assumption because men also collect fuelwood, and wood for house construction and for use in agricultural fields, yet are not barred from sacred forests.

Patriarchy is dominant in Indian society and men's control of activities associated with sacred forests shows this power imbalance. Taboos are both religious and traditional, with women kept away from sacred forests through this system of taboos. Thus women's status in the household and community, societal norms and religion dictate their relation with the sacred forests. The younger generation is increasingly questioning this gender inequity and advocating for equality in access to sacred forests and temples. During the time of our interviews, several women's groups were trying to enter temples in India from which they had until then been traditionally barred (Prasanna, 2016; Bijukumar, 2019). This budding movement could have affected some of the perspectives of the younger generation interviewed.

\section{Women and forest conservation}

We conclude that women have little say in the management of the sacred forests we studied. However, although the sacred forest tradition has survived without women's involvement, we found that some of the sacred forests had disappeared or were declining. We suggest that this problem could be addressed by increased participation of women in the decision-making processes for sacred forests.

It has been well established that women's participation has a positive impact in community forestry (Agarwal, 2009, 2010; Leisher et al., 2016). Agarwal (2009, p. 2796) noted that 'women's greater participation in the governance structure of an institution protecting a common pool 
resource, such as a forest, leads to better resource conservation and regeneration', and women have a beneficial impact on conservation outcomes because of their compliance with rules. Women's participation in decision-making and implementation of forest protection has a positive effect on the control of illegal grazing, illegal felling, and regeneration. On examining 675 village-level forest protection committees in Madhya Pradesh, India, they found that women's participation was associated with an increase of $24 \%$ in the probability of controlling illicit grazing, an increase of $28 \%$ in probability of controlling illicit felling, and an increase of $28 \%$ in probability of forest regeneration (Agrawal et al., 2006).

Further evidence supporting women's role in strengthening and reviving the tradition of sacred forests comes from east-central India. Borde \& Jackman (2010) describe a women's environmental movement that has led to the creation and regeneration of several hundred sacred forests dedicated to a pre-Sanskritic earth goddess. Women were traditionally prohibited from entering the sacred forests and performing rituals as they were believed to have a polluting influence. But now, despite facing censure from men in their community, the women have taken over neglected sacred forests, restored biodiversity by planting native and culturally important species such as sal Shorea robusta and karam Nauclea parvifolia, and imposed taboos on tree cutting (Borde \& Jackman, 2010). In Mendha (Lekha) and Pachgaon villages the Community Forest Resource provision of the Forest Rights Act has been successfully implemented, with the men and women having collectively decided to set apart substantial forest areas as strictly protected sacred forests (Gadgil, 2018).

The interactions of women with sacred forests have until now been restricted but this evidence from other studies shows there is scope for women in the Bhimashankar region to be more involved in sacred forest conservation and management. Women in Bhimashankar expressed the need to reforest sparse sacred forests and are actively participating in reviving bio-cultural diversity. Additionally, they expressed interest in continuing the sacred forest tradition. As in other places, their involvement could strengthen the institution. But for that to occur, the sacred forest institution will have to adapt to changing conditions, and allow equal involvement of women. Following such changes, it would be valuable to examine any changes in the integrity and biodiversity of sacred forests where women have been given this more inclusive role.

Acknowledgements We acknowledge the financial support provided by the Randolph G. Pack Environmental Institute (Department of Environmental Studies) and Graduate Student Association Research grant of State University of New York, College of Environmental Science and Forestry. We thank Kalpavriksh and Subhash Dolas, Minal Sonawne and Lila Bhomale for their help with fieldwork, and all the villagers who took the time to talk with us, and acknowledge the constructive feedback provided by Martin Fisher, Helen Anthem and two anonymous reviewers.

Author contributions Study design, fieldwork, data analysis: SM; writing: SM, SAWD.

\section{Conflicts of interest None.}

Ethical standards This study was authorized on 17 August 2015 by Syracuse University's Institutional Review Board (IRB \# 15-210), and the research otherwise abided by the Oryx guidelines on ethical standards.

\section{References}

Acharya, A. \& Ormsby, A. (2017) The cultural politics of sacred groves: a case study of devithans in Sikkim, India. Conservation \& Society, 15, 232-242.

Agarwal, B. (2009) Gender and forest conservation: the impact of women's participation in community forest governance. Ecological Economics, 68, 2785-2799.

Agarwal, B. (2010) Gender and Green Governance: The Political Economy of Women's Presence Within and Beyond Community Forestry. Oxford University Press, Oxford, UK.

Agrawal, A., Yadama, G., Andrade, R. \& Bhattacharya, A. (2006) Decentralization and Environmental Conservation: Gender Effects from Participation in Joint Forest Management. CAPRi working papers, 53. International Food Policy Research Institute, Washington, DC, USA.

Allendorf, T., Brandt, J. \& YAng, J. (2014) Local perceptions of Tibetan village sacred forests in northwest Yunnan. Biological Conservation, 169, 303-310.

Bernard, R.H. (2006) Research Methods in Anthropology: Qualitative and Quantitative Approaches. 4th edition. Rowman Altamira, Lanham, USA.

Bhagwat, S., Kushalappa, C.G., Williams, P.A. \& Brown, N.D. (2005) The role of informal protected areas in maintaining bio-diversity in the Western Ghats of India. Ecology and Society, 10, 8.

Bhagwat, S., Nogué, S. \& Willis, K.J. (2013) Cultural drivers of reforestation in tropical forest Groves of the Western Ghats of India. Forest Ecology and Management, 329, 393-400.

Bhagwat, S. \& Rutte, C. (2006) Sacred groves: potential for biodiversity management. Frontiers in Ecology and the Environment, 4, 519-524.

BIJUKUMAR, V. (2019) When religious faith mutilates gender equality: women entry in Sabarimala Temple in Kerala. ANTYAJAA: Indian Journal of Women and Social Change, 4, 238-244.

Borde, R. \& JACKMAN, A. (2010) The devi as ecofeminist warrior: reclaiming the role of sacred natural sites in east-central India. In Sacred Natural Sites: Conserving Nature and Culture (eds B. Verschuuren, R. Wild, J. McNeely \& G. Oviedo), pp. 272-279. Earthscan, London, UK.

BORGES, R. (1996) Joint management of Bhimashankar Wildlife Sanctuary. In People and Protected Areas: Towards Participatory Conservation in India (eds A. Kothari, N. Singh \& S. Suri), pp. 151-166. Sage Publications, New Delhi, India.

Burman, J.J.R. (2003) Sacred Groves Among Communities: The Mahadeo Kolis and the Kunbis of the Western Ghats. Mittal Publications, New Delhi, India.

Chandrakanth, M.G., Bhat, M.G. \& Accavva, M.S. (2004) Socio-economic changes and sacred groves in South India: protecting a community-based resource management institution. Natural Resources Forum, 28, 102-111. 
Chandran, M.D.S. (1998) Shifting cultivation, sacred groves and conflicts in colonial forest policy in the Western Ghats. In Nature and the Orient: The Environmental History of South and Southeast Asia (eds Richard H. Grove, V. Damodaran \& S. Sangwan), pp. 674-707. Oxford University Press, New Delhi, India.

Chandran, M.D.S. \& Hughes, J.D. (2000) Sacred groves and conservation: the comparative history of traditional reserves in the Mediterranean Area and in South India. Environment and History, $6,169-186$.

Cox, M., Villamayor-Tomas, S. \& Hartberg, Y. (2014) The role of religion in community-based natural resource management. World Development, 54, 46-55.

Deshmu k, S. (1999) Conservation and Development of Sacred Groves in Maharashtra. Final Report of the World Bank aided Maharashtra Forestry Project submitted to the Department of Forests, Government of Maharashtra. Bombay Natural History Society, Mumbai, India.

GadgiL, M. (2018) They are people's trees. Down to Earth. downtoearth.org.in/news/they-are-people-s-trees-59430 [accessed 15 August 2020].

GAdGiL, M. \& VARTAK, V.D. (1976) The sacred groves of Western Ghats in India. Economic Botany, 30, 152-160.

KALA, C.P. (2011) Traditional ecological knowledge, sacred groves and conservation of biodiversity in the Pachmarhi biosphere reserve of India. Journal of Environmental Protection, 2, 967-973.

Kandari, L.S., Bisht, V.K., Bhardwaj, M. \& Thakur, A.K. (2014) Conservation and management of sacred Groves, myths and beliefs of tribal communities: a case study from north-India. Environmental Systems Research, 3, 1-10.

Kent, E.F. (2010) A road runs through it: changing meanings in a sacred grove in Tiruvannamalai, Tamil Nadu. Journal for the Study of Religion, Nature \& Culture, 2, 213-231.

Kent, E.F. (2013) Sacred Groves and Local Gods: Religion and Environmentalism in South India. Oxford University Press, Oxford, UK.

Lebbie, A.R. \& Freudenberger, M.S. (1996) Sacred groves in Africa: forest patches in transition. In Forest Patches in Tropical Landscapes (eds J. Schelhas \& R. Greenberg), pp. 300-324. Island Press, Washington, DC, USA.

Leisher, C., Temsah, G., Booker, F., Day, M., Samberg, L., Prosnitz, D. et al. (2016) Does the gender composition of forest and fishery management groups affect resource governance and conservation outcomes? A systematic map. Environmental Evidence, 5, 1-10.

Maнabal, A. (2009) An overview. In Fauna of Bhimashankar Wildlife Sanctuary (Maharashtra) Conservation Area Series,
Vol. 42, pp. 1-12. Publication Division, Zoological Survey of India, Kolkata, India.

Malhotra, K.C., Gokhale, Y., Chatterjee, S. \& Srivastava, S. (2001) Cultural and Ecological Dimensions of Sacred Groves in India. Indian National Science Academy, New Delhi \& Indira Gandhi Rashtriya Manav Sangrahalaya, Bhopal, India.

Newing, H., Eagle, C.M., Puri, R.K. \& Watson, C.W. (2011) Conducting Research in Conservation: A Social Science Perspective. Routledge, Abingdon, UK.

Notermans, C., Nugteren, A. \& Sunny, S. (2016) The changing landscape of sacred groves in Kerala (India): a critical view on the role of religion in nature conservation. Religions, 7, 38.

Ormsiy, A. (2013) Analysis of local attitudes toward the sacred groves of Meghalaya and Karnataka, India. Conservation and Society, 11,187 .

Ormsby, A. \& Bhagwat, S. (2010) Sacred forests of India: a strong tradition of community-based natural resource management. Environmental Conservation, 37, 320-326.

Pande, P. \& Pathak, N. (2005) National Parks and Sanctuaries in Maharashtra: Individual Profile and Management Status, Vol. 2. Bombay Natural History Society, Bombay, India.

Prasanna, C.K. (2016) Claiming the public sphere: menstrual taboos and the rising dissent in India. Agenda, 30, 91-95.

Rahangdale, S. \& Rahangdale, S. (2017) Floristic diversity of Bhimashankar Wildlife Sanctuary, northern Western Ghats, Maharashtra, India. Journal of Threatened Taxa, 9, 10493-10527.

Rao, Y.L.P., Mangrulkar, R. \& Ben, C.V. (2008) Management Plan for the Bhimashankar Wildlife Sanctuary. Government of Maharashtra Revenue and Forests Department, Pune, India.

Ray, R., Chandran, M.D.S. \& Ramachandra, T.V. (2014) Biodiversity and ecological assessments of Indian sacred groves. Journal of Forestry Research, 25, 21-28.

Saldana, J. (2009) The Coding Manual for Qualitative Researchers. SAGE Publications, Thousand Oaks, USA.

Sered, S. (1999) Women of the Sacred Groves: Divine Priestesses of Okinawa. Oxford University Press, Oxford, UK.

Sheridan, M.J. \& Nyamweru, C. (eds) (2008) African Sacred Groves: Ecological Dynamics and Social Change. James Currey Press, Athens, USA.

SingH, N. (2006) A Study of Human Impact on Sacred Groves in India. Ohio University, Athens, USA.

Wild, R. \& McLeod, C. (2008) Sacred Natural Sites: Guidelines for Protected Area Managers. IUCN, Gland, Switzerland.

Zoological Survey of India (2009) Fauna of Bhimashankar Wildlife Sanctuary (Maharashtra). Conservation Area Series, 42. Publication Division, Zoological Survey India, Kolkata, India. 